\title{
Analysis of the Effects of the Housing Foundation Activities on Economic and Environmental Development of Rural Settlements: A Case Study of Moghan (Germi) County Villages
}

\author{
Firouz Mahdizadeh Kalansara' \\ Mahdi Jahani" \\ Mohammad Ali Ahmadian"II
}

\begin{abstract}
The Islamic Revolution Housing Foundation was established as the first executive body of the country in 1979 with the aim of helping the construction of housing for the deprived. Later, conductive (Hadi) plan preparation, conductive plan execution and the issuance of ownership document were added to the duties of the Foundation. Case studies are needed in order to understand the quality of the topics and the results of preparation and implementation of these plans. Accordingly, in this research, conductive plans, rural housing plans and eligible rural ownership documents in Moghan (Germi) County villages have been addressed. These plans have been implemented in 55 villages of the county. Thus, in the present study, we have investigated the effects of the Housing Foundation activities on economic and environmental development of Germi County villages. Here, a descriptive-analytical method based on documentary studies and field operations (questionnaire, interview, etc.) has been employed. Given the number of villages and the high number of households living in the villages, a sample size of 287 households was determined using Cochran formula and was distributed among the households in each village based on a systematic random sampling method. The research result based on the correlation coefficient test demonstrates that there is no significant relationship between the Housing Foundation activities and economic development of villages ( $p$-value> 0.05 ). Therefore, the research hypothesis is rejected at a $95 \%$ confidence level. Further, the relationship between the Housing Foundation activities and environmental development of villages is not significant ( $p$-value> 0.05 ). Hence, the hypothesis is rejected at a $95 \%$ confidence level.
\end{abstract}

Keywords: Conductive plan; Rural housing; Economic and environmental development; Moghan (Germi) County

IPHD Student, Department of Geography, Mashhad Branch, Islamic Azad University, Mashhad, Iran F.Mahdizadehkalansara@gmail.com

"Assistant Professor, Department of Geography, Mashhad Branch, Islamic Azad University, Mashhad, Iran Jahanimehdi94@gmail.com

I'Associate Professor, Department of Human Geography, Mashhad Branch, Islamic Azad University, Mashhad, Iran - Ahmadian@ferdowsi.um.ac.ir 


\section{Introduction}

One of the institutions that today is considered as the most important custodian and governmental body responsible for rural development is the Islamic Revolution Housing Foundation. It is one of the strategic institutions in the physical planning and management process in villages, which helps the rural development through the physical path. Hence, it is essential to pay attention to this institution in rural management from different dimensions (socio-economic and environmental-spatial). The main purpose of rural planning is to create the conditions for making the most of the available facilities and achieving the determined goal of growth and development in rural life in the shortest time (Moqaddam, 1993).

From the beginning of its formation and after 40 years of activity, the Housing Foundation has been able, within the framework of assigned tasks, to implement a wide range of measures in villages and towns with a population of under 25,000. From a total of works done by this institution until the decade of Imam Khomeini Account No. 100 in 2019, 38,000 conductive plans were prepared, of which 18,000 plans were executed. Moreover, it has transferred 2.1 million rural housing units and 3.3 million rural and urban documents (Islamic Revolution Housing Foundation site). Considering the importance and role of the Housing Foundation and the impact of its activities on advancing rural development goals, limited studies in this field along with its dominant approaches and views should be analyzed in order to recognize its weaknesses and strengths so that corrective and practical solutions to improve the entrepreneurial role of the Housing Foundation in sustainable development of rural areas are provided. Rural migration to cities in Iran can be studied from four economic, social, demographic and natural and agriculture dimensions. In this respect, this foundation plays a major role in the economic dimension and villagers migrate to improve their life and earn more money (Young Journalists Club, 2017, the cause of rural migration to metropolises).

With regard to the importance of rural areas mentioned above, the imbalance between rural and urban settlements and lack of systematic planning in various social, economic, cultural and physical areas have led to the disturbance of spatial order of 
settlements on one hand and accelerated growth of cities, especially first-order and secondorder cities, and increasing deprivation of villages compared to cities on the other (Molaei Hashtjin, 2002: 51), resulting in rural poverty, inequality within the rural community, migrations and consequently evacuation of rural areas, environmental vulnerability of villages, unemployment and the problem of employment in rural areas (Rezvani, 2011: 22). The role played by villages in the development of countries today makes the existence of planning essential for rural development. In different countries, depending on the type of government, state affairs are entrusted to governments. The establishment of governments has various purposes. But one of the most fundamental goals is to provide welfare and development for individuals in society and governments use a variety of tools to achieve these goals (Saeidi et al., 2006).

In investigating the economic statistics of implementing the conductive plan, Azizpour concluded that the execution of this plan has led to increased investment, employment growth and increased income of villagers (Azizpour, 2011).

Rural settlements have functions in advanced countries, the most important of which is the cultural and economic function and any rural housing policy should be tailored to the role and function of these houses (Mandal, 1989).

There is a significant relationship between the implementation of rural conductive plans with the creation of new job opportunities and increased rural incomes (Zarabi \& Parikhani Eslami, 2011: 40). Changing economic perspectives from agriculture to industry and services as an interconnected set has been effective in changing the functions (Seydaei et al., 2012: 39). Expansion of credits in other dimensions, especially job creation and entrepreneurship, can improve these dimensions of quality of life through increased income of villagers and make positive effects (Eslami et al., 2013: 40). The level of employment in agriculture and livestock farming has decreased and on the contrary, wage labor and the tendency towards non-agricultural activities have a greater share in the livelihood of these people (Ardehaei et al., 2013: 62). Implementation of the conductive plan, due to the creation of some non-agricultural activities and jobs, especially during the plan execution, has partly been able to relatively increase the income of some groups (Rezaei et al., 2013: 63). 
Housing construction has been able to provide a sense of security and comfort for families by increasing housing strength and resistance and prepare them to deal with future accidents (Einali, et al., 2014: 9). Rural housing improvement credits have had positive outcomes in the physical and environmental dimensions (Rezaei et al., 2012: 8). The limits of floodways should be determined by deducting the lands of the limits during the issuance of ownership documents (Negarandeh, 2018). The issuance of document provides security and peace of mind for the villagers and encourages residents to live in rural areas (Negarandeh, 2018).

Implementation of the conductive plan in villages lacking such a plan has had positive effects, in the environmental dimension, on the variables of cleanliness of the village, animal waste depot, avoidance of house construction on steep and dangerous lands, avoidance of the establishment of residential units in the limits of floods and rivers, reduced waste and pollution of water resources and decreased soil degradation and erosion (Mohammadi et al., 2012: 108).

According to the results of the 2016 General Census of Population and Housing, out of the total population of $79,926,270$ people in the country, $20,730,625$ people (25.9\%) live in villages and this population has been distributed in 62,284 villages. From a total population of 1,248,488 people in Ardabil Province, 404,236 people (32.2\%) reside in villages and this population has been distributed in 1859 villages. Besides, out of a population of 76,901 people in Moghan (Germi) County, 45,279 people (59\%) live in villages (Statistical Center of Iran, 2016).

It is necessary to pay attention to the physical organization of rural settlements in order to realize social and economic justice and raise quantitative and qualitative indicators of rural settlements with regard to the presence of $59 \%$ of villagers in rural settlements. Despite the presence and services of the Islamic Revolution Housing Foundation and implementation of large-scale projects by this institution for the spatial-physical organization of rural settlements, there is no clear picture of the changes made by this revolutionary institution. 
The present study is an applied research in terms of purpose, whose results can be used in planning. In order to achieve the desired results and evaluate the activities of the Housing Foundation in the sustainable development of rural settlements, from the sample villages, three dimensions for the Housing Foundation activities (preparation and implementation of the conductive plan, rural housing and rural ownership document) and two dimensions for sustainable rural development (economic and environmental) have been considered and indicators and items have been defined for each, which are presented in the following conceptual model.

Figure 1 - Conceptual model for the effects of the Housing Foundation activities on economic and environmental development of rural settlements

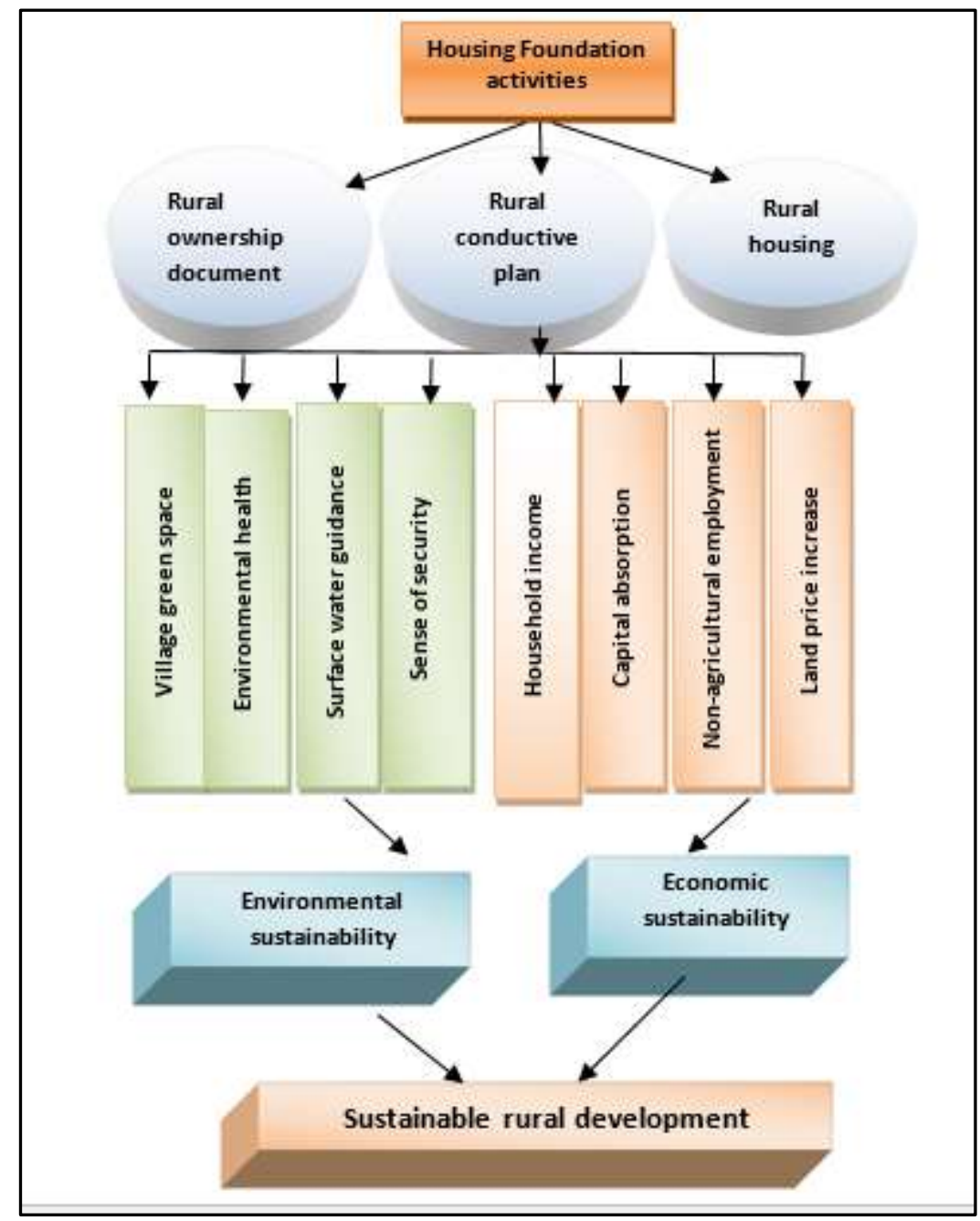




\section{Materials and methods}

\subsection{Location of the area under study}

Germi County neighbors Parsabad County and Bileh Savar County in the north, Kalibar and Ahar County (East Azerbaijan) in the west, Meshgin Shahr County in the south and Republic of Azerbaijan- Jalilabad and Yardymli in the east. This county is bounded by the slope of the Salavat Mountains to the south, the Khoruslu Mountains to the north, Darreh Rud to the west and Balharud to the east. Based on country divisions, Moghan (Germi) County has an area equivalent to 2049 square kilometers (Figure 2).

Figure 2 - Location of the studied area

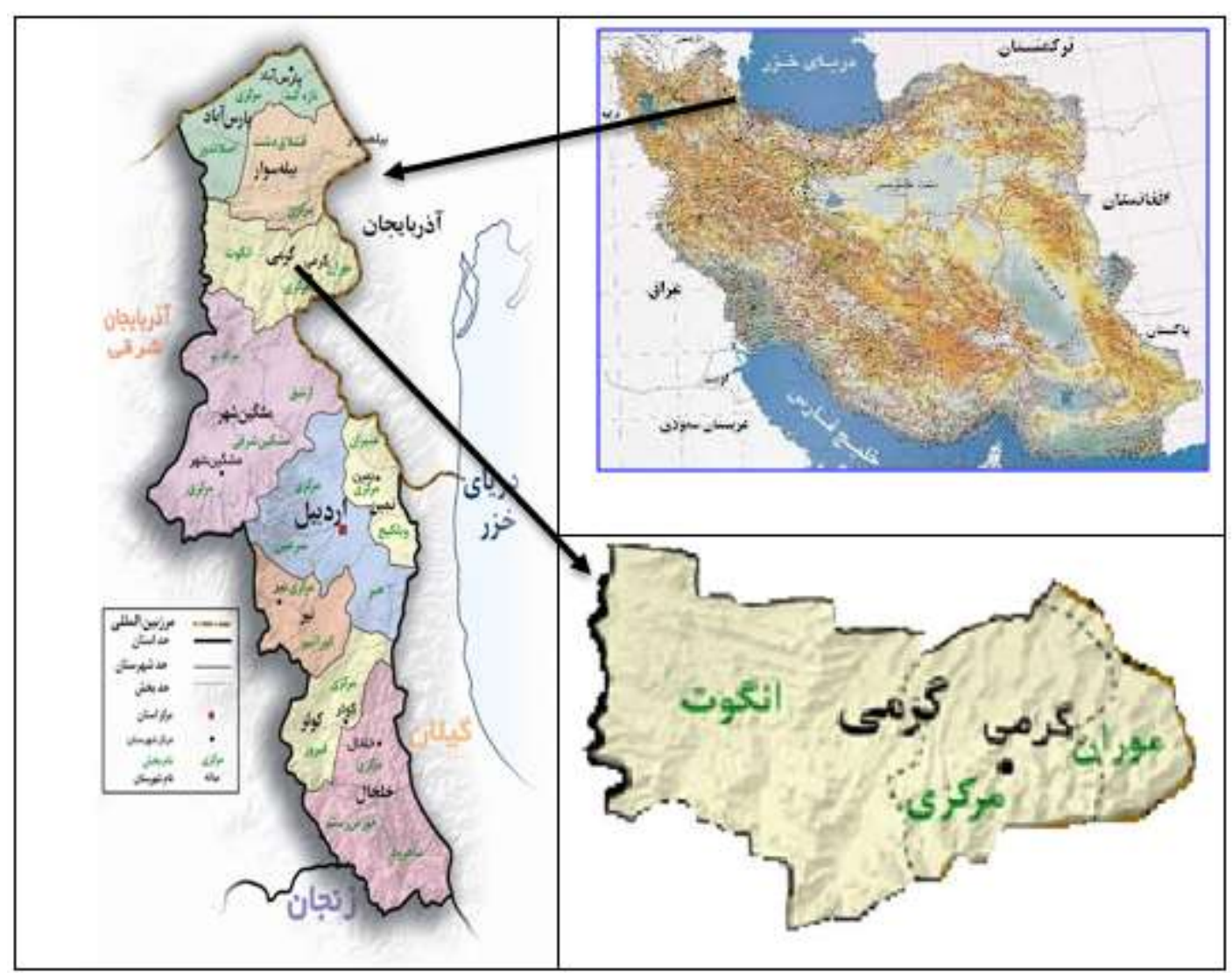




\subsection{Research method}

To study the effect of the Housing Foundation activities on the development of rural settlements, a descriptive-correlational research method has been applied. With regard to the research question, the research method is a survey based on questionnaire completion. Also, it is an applied study in terms of purpose and a descriptive-analytical study in terms of nature and method. The statistical population consists of Germi County villages. The studied four activities of the Housing Foundation, including conductive plan preparation, conductive plan execution, issuance of ownership document and reinforcement of rural areas, have mainly been done in 55 villages out of the 317 inhabited villages of this county. Initially, eligible villages were classified into 5 groups. Then, $20 \%$ of the villages (12 villages) were randomly selected according to the frequency of each group. The Cochran formula has been used to select the sample size. By putting the variance obtained from the pretest, $\mathrm{N}=287$ has been calculated, which was divided among the sample villages according to the household and was distributed within each village based on a systematic random sampling method. At first, the plans were prepared and the documents related to implementation were reviewed and studied. In the next step, the views of villagers and influential people in this regard were gathered through questionnaires. In order to prepare an appropriate questionnaire, the effective variables in plan execution were first determined by the exploratory method. After the initial test and assessment of the questionnaire validity and reliability using $10 \%$ of the actual sample, the final questionnaire was prepared and adjusted. In the final analysis, inferential statistics method, especially correlation, multivariate regression, etc., was used with the aid of SPSS software.

\section{Results}

Two variables of the Foundation activities and sustainable development were measured using Likert scale questions. Each of these two variables contains dimensions and each dimension is composed of components. In the table below, the frequency of choosing each option and the percentage obtained for each option in each question are presented. 
Table 1 - Frequency distribution of choosing the options of the questions in the second part of the questionnaire in measuring the Foundation activities

\begin{tabular}{|c|c|c|c|c|c|c|c|c|}
\hline Dimension & Component & Items & Indicator & $\begin{array}{l}\text { Very } \\
\text { low }\end{array}$ & Low & Medium & High & $\begin{array}{l}\text { Very } \\
\text { high }\end{array}$ \\
\hline \multirow{16}{*}{$\begin{array}{r}\text { Rural } \\
\text { housing }\end{array}$} & \multirow{4}{*}{$\begin{array}{c}\text { Housing } \\
\text { improvement }\end{array}$} & \multirow{2}{*}{$\begin{array}{l}\text { Durability } \\
\text { and quality of } \\
\text { newly-built } \\
\text { housing of the } \\
\text { Foundation }\end{array}$} & Frequency & 2 & 2 & 26 & 123 & 142 \\
\hline & & & Percentage & 0.7 & 0.07 & 8.8 & 41.7 & 48.1 \\
\hline & & \multirow{2}{*}{$\begin{array}{l}\text { Satisfaction } \\
\text { with the quality } \\
\text { of the facade } \\
\text { and appearance } \\
\text { of the houses } \\
\text { built by the } \\
\text { Foundation }\end{array}$} & Frequency & 2 & 0 & 48 & 128 & 117 \\
\hline & & & Percentage & 0.7 & 0.0 & 16.3 & 43.4 & 39.7 \\
\hline & \multirow{4}{*}{$\begin{array}{l}\text { Housing } \\
\text { reconstruction }\end{array}$} & \multirow{2}{*}{\begin{tabular}{l}
\multicolumn{1}{c}{ Family's } \\
sense of \\
security against \\
earthquake by \\
housing \\
construction
\end{tabular}} & Frequency & 1 & 4 & 33 & 114 & 141 \\
\hline & & & Percentage & 0.3 & 1.4 & 11.3 & 38.9 & 48.1 \\
\hline & & \multirow{2}{*}{\begin{tabular}{l}
\multicolumn{2}{c}{ Satisfaction } \\
with durable \\
materials used
\end{tabular}} & Frequency & 3 & 2 & 37 & 131 & 122 \\
\hline & & & Percentage & 1.0 & 0.7 & 12.5 & 44.4 & 41.4 \\
\hline & \multirow{4}{*}{$\begin{array}{l}\text { Housing } \\
\text { status }\end{array}$} & \multirow{2}{*}{\begin{tabular}{l}
\multicolumn{2}{c}{ Satisfaction } \\
with the \\
infrastructure of \\
residential units
\end{tabular}} & Frequency & 0 & 5 & 49 & 131 & 107 \\
\hline & & & Percentage & 0.0 & 1.7 & 16.8 & 44.9 & 36.6 \\
\hline & & \multirow{2}{*}{\begin{tabular}{lr}
\multicolumn{2}{c}{ Satisfaction } \\
with the \\
number of \\
rooms in rural \\
housing \\
\end{tabular}} & Frequency & 0 & 12 & 80 & 131 & 69 \\
\hline & & & Percentage & 0.0 & 4.1 & 27.4 & 44.9 & 23.6 \\
\hline & \multirow{4}{*}{ Quality of life } & \multirow{2}{*}{$\begin{array}{l}\text { Satisfaction } \\
\text { with the } \\
\text { exploitation of } \\
\text { the southern } \\
\text { light }\end{array}$} & Frequency & 2 & 16 & 60 & 122 & 94 \\
\hline & & & Percentage & 0.7 & 5.4 & 20.4 & 41.5 & 32.0 \\
\hline & & \multirow[b]{2}{*}{$\begin{array}{l}\text { Enhanced } \\
\text { beautification } \\
\text { of the } \\
\text { landscape and } \\
\text { environment of } \\
\text { the village by } \\
\text { housing } \\
\text { construction }\end{array}$} & Frequency & 6 & 22 & 48 & 85 & 130 \\
\hline & & & Percentage & 2.1 & 7.6 & 16.5 & 29.2 & 44.7 \\
\hline
\end{tabular}




\begin{tabular}{|c|c|c|c|c|c|c|c|c|}
\hline & \multirow[t]{3}{*}{$\begin{array}{l}\text { Network of } \\
\text { passages }\end{array}$} & $\begin{array}{l}\text { Satisfaction } \\
\text { with the } \\
\text { renovation of } \\
\text { the village's } \\
\text { network of } \\
\text { passages by the } \\
\text { Foundation }\end{array}$ & Frequency & 13 & 4.4 & 18.8 & 138 & 25.3 \\
\hline & & Satisfaction & Frequency & 7 & 8 & 68 & 141 & 68 \\
\hline & & $\begin{array}{ll}\text { access } & \text { to } \\
\text { passages } & \text { in } \\
\text { traffic } & \\
\end{array}$ & Percentage & 2.4 & 2.7 & 23.3 & 48.3 & 23.3 \\
\hline & & Satisfaction & Frequency & 6 & 12 & 98 & 107 & 67 \\
\hline & Kerb building & $\begin{array}{l}\text { the square and } \\
\text { boulevard and } \\
\text { modifying the } \\
\text { length and } \\
\text { width of } \\
\text { passages }\end{array}$ & Percentage & 2.1 & 4.1 & 33.8 & 36.9 & 23.1 \\
\hline & & Satisfaction & Frequency & 13 & 30 & 89 & 114 & 42 \\
\hline $\begin{array}{l}\text { Conductive } \\
\text { plan }\end{array}$ & & $\begin{array}{l}\text { of atmospheric } \\
\text { conditions and } \\
\text { disposal of } \\
\text { surface water }\end{array}$ & Percentage & 4.5 & 10.4 & 30.9 & 39.6 & 14.6 \\
\hline & & Satisfaction & Frequency & 1 & 17 & 119 & 127 & 27 \\
\hline & Development & $\begin{array}{l}\text { the physical } \\
\text { development of } \\
\text { the village }\end{array}$ & Percentage & 0.3 & 5.8 & 40.9 & 43.6 & 9.3 \\
\hline & side & Satisfaction & Frequency & 24 & 56 & 109 & 68 & 37 \\
\hline & & $\begin{array}{l}\text { of agricultural } \\
\text { lands to non- } \\
\text { agricultural use }\end{array}$ & Percentage & 8.2 & 19.0 & 37.1 & 23.1 & 12.6 \\
\hline & & Satisfaction & Frequency & 3 & 37 & 116 & 92 & 42 \\
\hline & $\begin{array}{l}\text { Valuable } \\
\text { texture }\end{array}$ & $\begin{array}{l}\text { preservation, } \\
\text { revival and } \\
\text { restoration of } \\
\text { the village's } \\
\text { texture and } \\
\text { body }\end{array}$ & Percentage & 1.0 & 12.8 & 40.0 & 31.7 & 14.5 \\
\hline & & $\begin{array}{l}\text { Preserving } \\
\text { the }\end{array}$ & Frequency & 11 & 51 & 90 & 98 & 41 \\
\hline & & $\begin{array}{l}\text { identity of the } \\
\text { village in the } \\
\text { construction of } \\
\text { residential units }\end{array}$ & Percentage & 3.8 & 17.5 & 30.9 & 33.7 & 14.1 \\
\hline & Economic & & Frequency & 3 & 2 & 30 & 81 & 175 \\
\hline
\end{tabular}




\begin{tabular}{|c|c|c|c|c|c|c|c|c|}
\hline \multirow{7}{*}{$\begin{array}{l}\text { Ownership } \\
\text { document }\end{array}$} & & \begin{tabular}{l}
\multicolumn{2}{c}{ Increased } \\
price of land \\
and housing by \\
issuing an \\
ownership \\
document
\end{tabular} & Percentage & 1.0 & 0.7 & 10.3 & 27.8 & 60.1 \\
\hline & & Effectiveness & Frequency & 7 & 12 & 58 & 120 & 97 \\
\hline & & $\begin{array}{l}\text { document } \\
\text { issuance in } \\
\text { attracting funds } \\
\text { and facilities }\end{array}$ & Percentage & 2.4 & 4.1 & 19.7 & 40.8 & 33.0 \\
\hline & \multirow{4}{*}{ Social } & \multirow{2}{*}{$\begin{array}{l}\text { The effect of } \\
\text { document } \\
\text { issuance on } \\
\text { cooperation } \\
\text { and helping } \\
\text { each other }\end{array}$} & Frequency & 5 & 12 & 42 & 94 & 141 \\
\hline & & & Percentage & 1.7 & 4.1 & 14.3 & 32.0 & 48.0 \\
\hline & & \multirow{2}{*}{\begin{tabular}{ll}
\multicolumn{1}{c}{ Reduced } & \\
property & \\
disputes & by \\
issuing & an \\
ownership & \\
document &
\end{tabular}} & Frequency & 2 & 4 & 24 & 53 & 212 \\
\hline & & & Percentage & 0.7 & 1.4 & 8.1 & 18.0 & 71.9 \\
\hline
\end{tabular}

By taking a look at the item of durability and quality of newly-built houses of the Foundation, it can be seen that in most cases, the level has been evaluated to be very high (equal to $48.14 \%$ ). By examining the item of satisfaction with the quality of the facade and appearance of the houses built by the Foundation, it can be observed that in most cases, the level has been stated to be very high (43.39\%). With respect to the item of family's sense of security against earthquake by housing construction, it can be seen that in most assessments, the level has been stated to be high (48.12\%). In studying the item of satisfaction with durable materials used, it is observed that in most cases, the level has been evaluated to be very high (44.41\%). Investigation of the item of satisfaction with the infrastructure of residential units shows that in most evaluations, the level is medium (44.86\%). By looking at the item of enhanced beautification of the landscape and environment of the village by housing construction, it can be seen that in most cases, the level has been evaluated to be high (44.67\%). Study of the item of satisfaction with the renovation of the village's network of passages by the Foundation reveals that in most 
evaluations, the level is very high (47.1\%). By examining the item of satisfaction with ease of access to passages in traffic, it is revealed that in most assessments, the level is very high (48.29\%). Study of the item of satisfaction with creating the square and boulevard and modifying the length and width of passages indicates that in most evaluations, the level is very high (36.9\%). By reviewing the item of satisfaction with the quality of atmospheric conditions and disposal of surface water, it can be observed that in most cases, the level has been evaluated to be medium (39.58\%). Considering the item of satisfaction with land use in the physical development of the village, it can be seen that in most evaluations, the level is medium (43.64\%). Study of the item of increased price of land and housing by issuing an ownership document shows that in most cases, the level has been stated to be very high (60.14\%). By examining the item of effectiveness of rural document issuance in attracting funds and facilities, it is observed that in most evaluations, the level is very high (40.82\%). With regard to the item of the effect of document issuance on cooperation and helping each other, it is observed that in most evaluations, the level is very high (47.96\%). Study of the item of reduced property disputes by issuing an ownership document suggests that in most cases, the level has been evaluated to be high (71.86\%).

Table 2 - Frequency distribution of choosing the options of the questions in the second part of the questionnaire in measuring sustainable development

\begin{tabular}{|c|c|c|c|c|c|c|c|c|}
\hline $\begin{array}{l}\text { Dimensi } \\
\text { on }\end{array}$ & $\begin{array}{c}\text { Compon } \\
\text { ent }\end{array}$ & Items & $\begin{array}{l}\text { Indica } \\
\text { tor }\end{array}$ & $\begin{array}{r}v \\
\text { ery } \\
\text { low }\end{array}$ & $\begin{array}{r}L \\
\text { ow }\end{array}$ & $\begin{array}{l}\text { Med } \\
\text { ium }\end{array}$ & $\begin{array}{l}\mathrm{Hi} \\
\mathrm{gh}\end{array}$ & $\begin{array}{r}v \\
\text { ery } \\
\text { high }\end{array}$ \\
\hline \multirow[b]{2}{*}{ Economi } & \multirow[b]{2}{*}{$\begin{array}{l}\text { Employ } \\
\text { ment }\end{array}$} & \multirow{2}{*}{$\begin{array}{l}\text { The } \\
\text { amount } \\
\text { of } \\
\text { agricultur } \\
\text { al } \\
\text { develop } \\
\text { ment in } \\
\text { the } \\
\text { village }\end{array}$} & $\begin{array}{l}\text { Freque } \\
\text { ncy }\end{array}$ & 7 & $\begin{array}{c}1 \\
8\end{array}$ & 83 & $\begin{array}{l}12 \\
7\end{array}$ & 56 \\
\hline & & & $\begin{array}{l}\text { Percen } \\
\text { tage }\end{array}$ & $\begin{array}{l}2 . \\
4\end{array}$ & $\begin{array}{l}6 . \\
2\end{array}$ & 28.5 & $\begin{array}{l}43 \\
.6\end{array}$ & $\begin{array}{l}19 \\
.2\end{array}$ \\
\hline
\end{tabular}




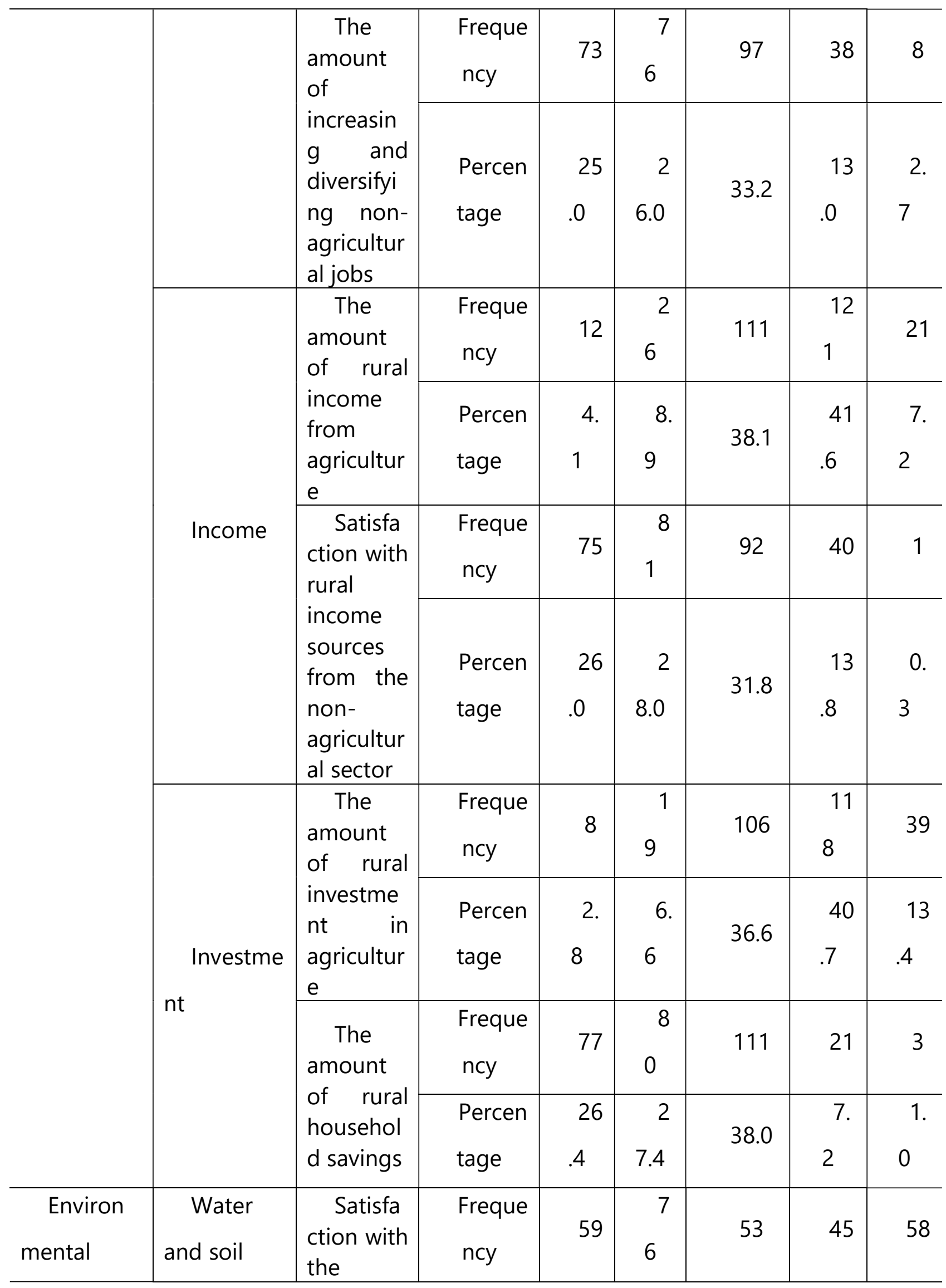




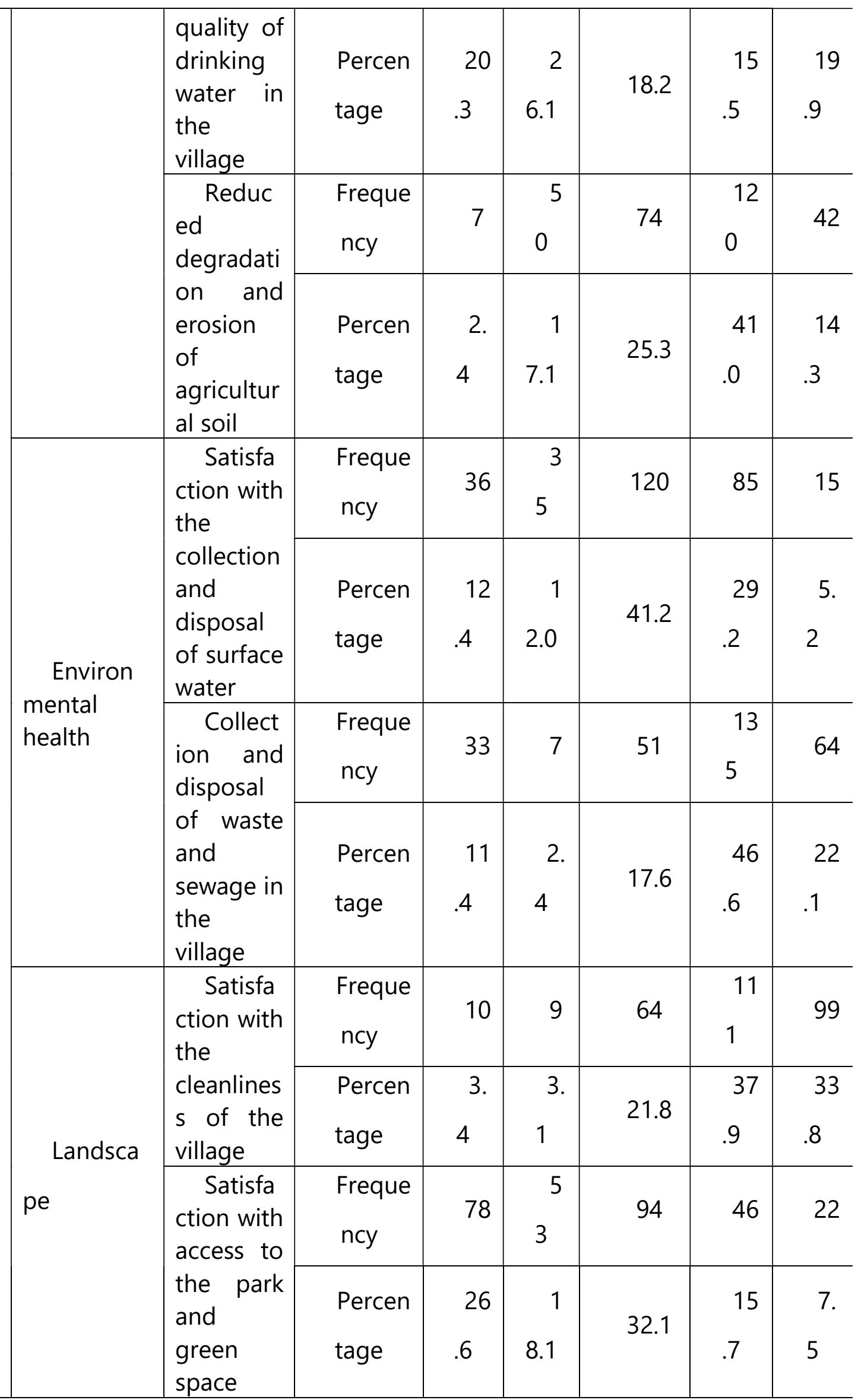


By reviewing the item of the amount of agricultural development in the village, it is observed that in most evaluations, the level is medium (equal to 43.64\%). With regard to the item of the amount of increasing and diversifying non-agricultural jobs, it can be seen that in most cases, the level has been evaluated to be very high (33.22\%). Study of the item of the amount of rural income from agriculture shows that in most cases, the level has been stated to be medium (41.58\%). By looking at the item of satisfaction with rural income sources from the non-agricultural sector, it is revealed that in most cases, the level is very high (31.83\%). Examination of the item of the amount of rural investment in agriculture, it is observed that in most evaluations, the level is very high (40.69\%). Considering the item of the amount of rural household savings, it is observed that in most cases, the level is very high (38.01\%). With regard to the item of satisfaction with the quality of drinking water in the village, it is revealed that in most evaluations, the level is very high (26.12\%). Study of the item of reduced degradation and erosion of agricultural soil, it can be seen that in most cases, the level has been stated to be very high (40.96\%). In examining the item of satisfaction with the collection and disposal of surface water, it can be seen that in most cases, the level is very high (41.24\%). Study of the item of the collection and disposal of waste and sewage in the village, it is observed that in most evaluations, the level has been stated to be medium (46.55\%). Considering the item of satisfaction with the cleanliness of the village, it is revealed that in most cases, the level is medium (37.88\%). Study of the item of satisfaction with access to the park and green space suggests that in most cases, the level is very high (32.08\%).

\subsection{Study of the economic dimension of sustainable development}

The economic dimension consists of three components: Employment, income and investment. To measure these components, economic questions with a Likert scale similar to the rural housing variable are used. The method of calculating the scores of the components of this variable is similar to the components of rural housing described in the previous section. 
Table 3 - Descriptive indicators of the economic dimension

\begin{tabular}{l|c|c}
\hline $\begin{array}{c}\text { Economic } \\
\text { components }\end{array}$ & Mean & SD \\
\hline Employment & 3.063 & 0.751 \\
\hline Income & 2.874 & 0.716 \\
\hline Investment & 2.911 & 0.744 \\
\hline Economic & 2.949 & 0.611 \\
\hline
\end{tabular}

After examining the three components, it is observed that employment with a mean value of 3.063 has the greatest mean and income with a mean of 2.874 has the lowest mean value. Only one component has a mean value above the medium level (3).

\subsection{Study of the environmental dimension of sustainable development}

The environmental dimension embraces the three components of water and soil, environmental health and landscape. To measure these components, environmental questions with a Likert scale similar to the rural housing variable are used. The method of calculating the scores of the components of this variable is similar to the components of rural housing described in the previous section. In Table (4), descriptive indicators of different environmental components are provided.

Table 4 - Descriptive indicators of the environmental dimension

\begin{tabular}{l|c|c}
\hline \multicolumn{1}{c|}{$\begin{array}{c}\text { Environmental } \\
\text { components }\end{array}$} & Mean & SD \\
\hline Water and soil & 3.188 & 0.886 \\
\hline Environmental health & 3.343 & 0.974 \\
\hline Landscape & 3.275 & 0.878 \\
\hline Environmental & 3.268 & 0.718 \\
\hline
\end{tabular}


Among the three components, the component of environmental health with a mean of 3.343 has the highest mean value and the component of water and soil with a mean of 3.188 has the lowest mean value. All components have mean values above the medium level (3).

Given the means calculated for this variable and its components, it is observed that Bil Dashi village has the highest mean and best status in all components and this variable.

Table 5 - Mean rural housing variable and its dimensions for each village

\begin{tabular}{|c|c|c|c|c|c|}
\hline Village & $\begin{array}{c}\text { Housing } \\
\text { improvemen } \\
t\end{array}$ & $\begin{array}{c}\text { Housing } \\
\text { reconstructio } \\
\mathbf{n}\end{array}$ & $\begin{array}{l}\text { Housin } \\
\text { g status }\end{array}$ & $\begin{array}{l}\text { Qualit } \\
\text { y of life }\end{array}$ & $\begin{array}{l}\text { Rural } \\
\text { housin } \\
\mathbf{g}\end{array}$ \\
\hline Omaslan & 4.71 & 4.55 & 4.19 & 4.62 & 4.52 \\
\hline $\begin{array}{l}\text { Gede } \\
\text { Kahriz }\end{array}$ & 4.47 & 4.53 & 3.97 & 4.57 & 4.38 \\
\hline Gilarlu & 4.37 & 4.50 & 3.77 & 4.37 & 4.25 \\
\hline Azadlu & 4.44 & 4.44 & 4.29 & 4.35 & 4.38 \\
\hline $\begin{array}{l}\text { Parchin-e } \\
\text { Sofla }\end{array}$ & 4.38 & 4.10 & 4.13 & 3.92 & 4.13 \\
\hline Takanlu & 3.98 & 4.20 & 3.59 & 3.70 & 3.87 \\
\hline $\begin{array}{l}\text { Hachakand } \\
\text {-e Darmanlu }\end{array}$ & 4.21 & 4.21 & 3.88 & 3.50 & 3.95 \\
\hline $\begin{array}{l}\text { Qasem } \\
\text { Kandi }\end{array}$ & 3.98 & 4.13 & 3.75 & 3.73 & 3.90 \\
\hline Kalan Sara & 4.13 & 4.30 & 4.07 & 3.99 & 4.12 \\
\hline Ziveh & 4.26 & 4.06 & 3.94 & 3.80 & 4.02 \\
\hline Ani & 4.41 & 4.36 & 4.61 & 4.50 & 4.47 \\
\hline Bil Dashi & 4.82 & 4.91 & 4.68 & 4.64 & 4.76 \\
\hline
\end{tabular}


In Table (6), the mean of the conductive plan variable and its components are presented for each village. Considering the means calculated for this variable and its components, it is observed that Bill Dashi village has the highest mean and best status in all components except the component of the network of passages (in this component, Omasan village has the best status).

Table 6 - Mean conductive plan variable and its dimensions for each village

\begin{tabular}{|c|c|c|c|c|c|}
\hline Village & $\begin{array}{c}\text { Networ } \\
\mathbf{k} \text { of } \\
\text { passages }\end{array}$ & $\begin{array}{l}\text { Kerb } \\
\text { buildin } \\
\mathbf{g}\end{array}$ & $\begin{array}{l}\text { Developmen } \\
\text { t side }\end{array}$ & $\begin{array}{l}\text { Valuabl } \\
\text { e texture }\end{array}$ & $\begin{array}{l}\text { Conductiv } \\
\text { e plan }\end{array}$ \\
\hline Omaslan & 4.26 & 3.86 & 3.21 & 3.38 & 3.68 \\
\hline Gede Kahriz & 3.93 & 3.53 & 3.10 & 2.60 & 3.29 \\
\hline Gilarlu & 4.23 & 3.87 & 3.33 & 3.03 & 3.62 \\
\hline Azadlu & 4.15 & 3.91 & 3.26 & 3.35 & 3.67 \\
\hline $\begin{array}{l}\text { Parchin-e } \\
\text { Sofla }\end{array}$ & 3.90 & 3.50 & 3.10 & 3.04 & 3.39 \\
\hline Takanlu & 3.69 & 3.48 & 3.30 & 3.06 & 3.38 \\
\hline $\begin{array}{l}\text { Hachakand } \\
\text {-e Darmanlu }\end{array}$ & 4.00 & 3.79 & 3.16 & 3.13 & 3.52 \\
\hline $\begin{array}{l}\text { Qasem } \\
\text { Kandi }\end{array}$ & 3.38 & 3.22 & 3.20 & 3.18 & 3.25 \\
\hline Kalan Sara & 4.23 & 3.86 & 3.37 & 3.23 & 3.67 \\
\hline Ziveh & 3.67 & 3.45 & 3.50 & 3.46 & 3.51 \\
\hline Ani & 3.52 & 3.41 & 3.68 & 3.86 & 3.61 \\
\hline Bil Dashi & 3.68 & 4.05 & 4.00 & 4.18 & 3.98 \\
\hline
\end{tabular}

In Table (7), the mean of the ownership document variable and its components are provided for each village. Given the means calculated for this variable and its components, it can be seen that Parchin-e Sofla village has the highest mean and best status in the 
economic component and Azadlu village has the highest mean and best status in the social component and ownership document.

Table 7 - Mean ownership document variable and its dimensions for each village

\begin{tabular}{l|c|c|c}
\hline \multicolumn{1}{c|}{ Village } & Economic & Social & $\begin{array}{c}\text { Ownership } \\
\text { document }\end{array}$ \\
\hline Omaslan & 4.50 & 4.43 & 4.46 \\
\hline Gede Kahriz & 4.07 & 4.50 & 4.28 \\
\hline Gilarlu & 4.17 & 4.30 & 4.23 \\
\hline Azadlu & 4.44 & 4.88 & 4.66 \\
\hline Parchin-e Sofla & 4.52 & 4.71 & 4.61 \\
\hline Takanlu & 4.13 & 4.20 & 4.17 \\
\hline Hachakand-e & 4.39 & 4.61 & 4.50 \\
\hline Darmanlu & 3.95 & 4.20 & 4.08 \\
\hline Qasem Kandi & 4.03 & 4.34 & 4.19 \\
\hline Kalan Sara & 4.12 & 4.07 & 4.10 \\
\hline Ziveh & 4.07 & 4.55 & 4.31 \\
\hline Ani & 4.50 & 4.77 & 4.64 \\
\hline Bil Dashi & & & \\
\hline
\end{tabular}

Table (8) shows the mean economic development variable and its components for sample villages. Given the means calculated for this variable and its components, it is observed that Gede Kahriz village has the greatest mean and best status in all components except the component of income (in this component, Omaslan village has the best status).

Table 8 - Mean economic development variable and its dimensions for each village

\begin{tabular}{c|c|c|c|c}
\hline Village & Employment & Income & Investment & Economic \\
\hline Omaslan & 3.67 & 3.38 & 3.26 & 3.44 \\
\hline Gede Kahriz & 3.70 & 3.30 & 3.43 & 3.48 \\
\hline
\end{tabular}




\begin{tabular}{l|c|c|c|c}
\hline Gilarlu & 3.07 & 2.99 & 2.83 & 2.96 \\
\hline Azadlu & 2.62 & 2.41 & 2.62 & 2.55 \\
\hline Parchin-e Sofla & 2.88 & 2.69 & 2.71 & 2.76 \\
\hline Takanlu & 3.26 & 3.04 & 3.02 & 3.10 \\
\hline $\begin{array}{l}\text { Hachakand-e } \\
\text { Darmanlu }\end{array}$ & 2.66 & 2.80 & 2.79 & 2.75 \\
\hline Qasem Kandi & 2.90 & 2.81 & 2.81 & 2.84 \\
\hline Kalan Sara & 3.39 & 3.04 & 3.23 & 3.22 \\
\hline Ziveh & 3.21 & 2.99 & 3.14 & 3.11 \\
\hline Ani & 2.39 & 2.23 & 2.25 & 2.29 \\
\hline Bil Dashi & 2.77 & 2.45 & 2.14 & 2.45 \\
\hline
\end{tabular}

Table (9) displays the mean economic development variable and its components for sample villages. With respect to the means calculated for this variable and its components, it is observed that Omaslan village has the greatest mean and best status in all components except the component of water and soil (in this component, Gede Kahriz village has the best status).

Table 9 - Mean environmental development variable and its dimensions for each village

\begin{tabular}{c|c|c|c|c}
\hline Village & $\begin{array}{c}\text { Water } \\
\text { and soil }\end{array}$ & $\begin{array}{c}\text { Environmental } \\
\text { health }\end{array}$ & Landscape & Environmental \\
\hline Omaslan & 3.86 & 3.95 & 4.36 & 4.06 \\
\hline Gede Kahriz & 3.87 & 3.93 & 3.97 & 3.92 \\
\hline Gilarlu & 3.71 & 3.66 & 3.45 & 3.61 \\
\hline Azadlu & 2.97 & 3.53 & 3.47 & 3.32 \\
\hline Parchin-e & 2.88 & 3.63 & 3.33 & 3.28 \\
Sofla & 3.17 & 3.44 & 3.02 & 3.21 \\
\hline Takanlu & 2.73 & 3.75 & 3.21 & 3.23 \\
\hline $\begin{array}{l}\text { Hachakand-e } \\
\text { Darmanlu }\end{array}$ & & & & \\
\hline
\end{tabular}




\begin{tabular}{l|l|l|l|l}
\hline Qasem Kandi & 3.54 & 3.31 & 3.06 & 3.30 \\
\hline Kalan Sara & 3.01 & 3.59 & 3.53 & 3.38 \\
\hline Ziveh & 3.07 & 3.05 & 3.09 & 3.07 \\
\hline Ani & 2.89 & 2.36 & 2.68 & 2.64 \\
\hline Bil Dashi & 3.23 & 1.36 & 2.18 & 2.26 \\
\hline
\end{tabular}

Considering the importance and dependence of the Housing Foundation activities on the development of rural settlements, in this section, we investigate the relationship between the Housing Foundation activities and the economic development of villages in the whole sample and for each village under study (Table 10).

Table 10 - Results of investigating the correlation between the economic development of villages and the Housing Foundation Activities for each village

\begin{tabular}{l|c|c|c}
\hline \multicolumn{1}{c|}{ Village } & $\begin{array}{c}\text { Correlation } \\
\text { coefficient }\end{array}$ & $\begin{array}{c}\text { P- } \\
\text { value }\end{array}$ & $\begin{array}{c}\text { Number } \\
\text { of samples }\end{array}$ \\
\hline Omaslan & 0.311 & 0.170 & 21 \\
\hline Gede Kahriz & $0.675^{\star *}$ & 0.006 & 15 \\
\hline Gilarlu & 0.340 & 0.215 & 15 \\
\hline Azadlu & -0.260 & 0.314 & 17 \\
\hline Parchin-e Sofla & -0.129 & 0.550 & 24 \\
\hline Takanlu & 0.335 & 0.087 & 27 \\
\hline Hachakand-e & -0.001 & 0.995 & 28 \\
\hline Darmanlu & 0.272 & 0.146 & 30 \\
\hline Qasem Kandi & -0.046 & 0.795 & 35 \\
\hline Kalan Sara & 0.111 & 0.441 & 50 \\
\hline Ani & -0.399 & 0.066 & 22 \\
\hline Bil Dashi & -0.277 & 0.409 & 11 \\
\hline Whole sample & -0.019 & 0.745 & 295 \\
\hline
\end{tabular}


As can be observed in the above table, the relationship between the Housing Foundation activities and the economic development of villages is significant only in Gilarlu village. This relationship is positive and its severity is 0.675 . With an increase in the Housing Foundation activities in this village, the economic development of the village also increases and vice versa.

Table 11 - Results of investigating the correlation between the environmental development of villages and the Housing Foundation Activities for each village

\begin{tabular}{|c|c|c|c|}
\hline Village & $\begin{array}{l}\text { Correlation } \\
\text { coefficient }\end{array}$ & P-value & $\begin{array}{r}\text { Number } \\
\text { of samples }\end{array}$ \\
\hline Omaslan & $0.723^{* *}$ & 0.000 & 21 \\
\hline Gede Kahriz & 0.312 & 0.258 & 15 \\
\hline Gilarlu & $0.536^{*}$ & 0.040 & 15 \\
\hline Azadlu & $-0.706^{* *}$ & 0.002 & 17 \\
\hline $\begin{array}{l}\text { Parchin-e } \\
\text { Sofla }\end{array}$ & -0.265 & 0.210 & 24 \\
\hline Takanlu & 0.237 & 0.234 & 27 \\
\hline $\begin{array}{l}\text { Hachakand-e } \\
\text { Darmanlu }\end{array}$ & 0.287 & 0.138 & 28 \\
\hline Qasem Kandi & 0.033 & 0.862 & 30 \\
\hline Kalan Sara & -0.205 & 0.237 & 35 \\
\hline Ziveh & 0.263 & 0.064 & 50 \\
\hline Ani & -0.273 & 0.218 & 22 \\
\hline Bil Dashi & 0.246 & 0.466 & 11 \\
\hline $\begin{array}{l}\text { Whole } \\
\text { sample }\end{array}$ & 0.027 & 0.645 & 295 \\
\hline
\end{tabular}

The relationship between the Housing Foundation activities and the environmental development of villages is significant in the three villages of Omaslan, Gilarlu and Azadlu. 
This relationship is direct and positive in the two villages of Omaslan and Gilarlu. Thus, with an increase in the Housing Foundation activities in this village, the environmental development of the village also increases and vice versa. This relationship is inverse and negative In Azadlu village. In other words, as the Housing Foundation activities increase in Azadlu village, the rate of environmental development decreases.

\section{Conclusion}

The rural conductive plan has been considered as an organization tool in villages by providing the necessary ground for growth and development. With multidisciplinary study of the Housing Foundation activities, especially in the field of preparation and implementation of rural conductive plans, rural housing improvement and issuance of rural ownership document, the physical and non-physical dimensions of these activities can be revealed and by gathering and providing the information needed for better management of plans, the ground can be prepared for strengthening and sustaining the effects of the Housing Foundation activities on sustainable development of rural settlements.

The research findings indicated that the effects of the Housing Foundation activities on economic development of rural settlements based on the factor analysis results of these effects were studied in three categories of factors including employment, income and investment. Accordingly, the relationship between the Housing Foundation activities and economic development of villages is not significant ( $p$-value $>0.05$ ). Therefore, the economic hypothesis is rejected at a 95\% confidence level. Findings of this section of the research are not consistent with the results of the studies conducted by Amir Ahmadi et al. (2017), Asghari et al. (2016), Mohammadi Yeganeh et al. (2016), Rabi'ei et al. (2015), Annabestani et al. (2013), Saeidi et al. (2013), Qasemi Ardehaei et al. (2013), Torshizian and Athari (2010) and Azizpour et al. (2011).

It is suggested that native economic expert advisors be used in preparation and revision of plans with economic attachment and native workers be employed in the 
implementation of the conductive plan and reinforcement of residential units. Further, it is recommended to apply native and local materials in housing construction and implementation of the rural conductive plan and provide rural employment by creating small workshops related to the construction industry. Moreover, motivation should be generated for villagers to benefit from the tourism industry in rural tourism. Ownership document as a bank guarantee and the use of stagnant capital and livelihood-based housing construction for economic rehabilitation and issues of livelihood, manufacturing and handmade industry should be taken into account.

The research findings revealed that the effects of the Housing Foundation activities on environmental development of rural settlements based on the factor analysis results of these effects were studied in three categories of factors including water and soil, environmental health and landscape. Accordingly, the relationship between the Housing Foundation activities and environmental development of villages is not significant ( $p$ value $>0.05$ ). Hence, the environmental hypothesis is rejected at a $95 \%$ confidence level. Findings of this section of the research are not consistent with the results of the studies conducted by Haq Panah et al. (2009), Moradi et al. (2009), Taqilou et al. (2009), Moti'ei Langroudi (2010), Mohammadi et al. (2012), Mohammadi Yeganeh et al. (2013), Rezaei et al. (2013), Shamsoddini et al. (2015), Rezaei et al. (2012), Einali et al. (2014) and Rezaei et al. (2012). It is suggested that attempt is made to shorten the execution time of the plan by using a team of local supervisors at all three stages of evaluation (pre-implementation, during implementation and post-implementation) and taking advantage of (state-public) participatory management. A sapling should be planted for each family while obtaining a construction work completion certificate plus small rooted trees alongside the floodways to reduce soil degradation and erosion. Native materials should be used in passages for the disposal of surface water and encouragement of women to daily clean their living area. Creation of a proper landscape by building uniform units towards the entrance to the village and comprehensive cooperation in promptly collecting animal waste and directing it out of the village are recommended. 


\section{References}

Annabestani et al. (2013). Social and economic impacts of implementing the conductive plan in rural settlements of Dena County. Quarterly Journal of Regional Planning, 3(9).

Annabestani et al. (2013). The impact of rural housing improvement credits on improving the villagers' quality of life in four social, economic, physical and environmental dimensions. Journal of Housing and Environment, 142.

Azizpour et al. (2011). Analysis of the economic impacts of implementing the conductive plan in rural settlements of the country. Journal of Housing and Environment, 135.

Ekrami, Gh. R. (2014). The role of native materials in sustainable architecture from the environmental viewpoint of improvement of valuable rural textures in physical development of villages. Journal of Housing and Rural Environment, 156.

Eslami et al. (2013). Investigating the impact of rural housing improvement credits on improving the villagers' quality of life in four social, economic, physical and environmental dimensions. Journal of Housing and Environment, 148.

Golpayegani et al., (2013). Study of the rural housing plan and its impact on housing health and safety indicators. Journal of Housing and Environment, 144.

Mohammadi Yeganeh et al. (2016). Analysis of effective economic indicators in rural housing functional developments in Zanjan. Journal of Housing and Environment, 160.

Moti'ei Langroudi, H. (2010). Environmental protection and its place in physical development planning with emphasis on rural conductive plans. Journal of Geography and Environmental Planning.

Moti'ei Langroudi, H. (2010). Investigating the consequences of implementing the conductive plan for the environment of rural settlements. Comprehensive Portal for Humanities, Geography and Environmental Planning, 21(3).

Planning and Budget Organization of the country, Law of the Fourth Socio-Economic and Cultural Development Plan of the Islamic Republic of Iran (2015).

Rezaei et al. (2012). Investigating environmental problems in implementation of the conductive plan in Sarin Dizaj Village in Osko County. Proceedings of the Second National Conference on Environmental Management Planning, Tehran, April-May.

Shayan et al. (2013). Economic and social consequences of the plan for the issuance of ownership documents for areas in rural settlements of Eqlid County. Journal of Housing and Environment, 132. 
Statistical Center of Iran (2016). General Census of Population and Housing, General Results of Ardabil Province.

Statistical Center of Iran, General Census of Population and Housing (2011), Moghan (Germi) County.

Taqilou et al. (2009). Evaluation of conductive plans in physical, social and economic dimensions from the viewpoint of villagers in Komijan County. Proceedings of the First National Conference on Physical Development and Housing in Zahedan, September 30 and October 1.

The Islamic Revolution Housing Foundation (2013). Performance of the studies and implementation of the rural conductive plan. Deputy of Rural Development, Bonyad Publications, Tehran. 